\title{
The Ghosts of the Hope Natural Gas Decision
}

\author{
Hillyer, Brown*
}

TF THE Supreme Court had been content to treat the Hope Natural $I_{\text {Gas }}$ case $^{\mathrm{1}}$ as an occasion to celebrate the last rites for the "fair value" process of fixing utility rates expounded in Smyth v. Ames," it might perhaps have done a service in finally laying a ghost ${ }^{3}$ which appeared to be still at large despite the decision two years before in Federal Power Commission v. Natural Gas Pipeline Co. ${ }^{1}$ But the Court went much further-it not only tried to exorcise one ghost but in the process it set free several others which had long been at rest, and moreover it created some new ones of its own due to the utter impossibility of ascertaining any sensible basis for its decision. If the Court had set out to bedevil the public, the utilities and the commissions with a series of phantoms that will haunt rate making for years to come, it could hardly have done a more thorough job.

When the Court was first faced with the problem of passing on rate-fixing orders, it decided that "What the company is entitled to ask is a fair return upon the value of that which it employs for the public convenience." ${ }^{6}$ However, the value of a going concern ordinarily depends on its present and prospective earnings and since earnings depend on rates it was necessary, to avoid reasoning in a circle, to find some other method of determining value. Thus there came into being the concept of "fair value" which the regulatory body was required to ascertaim by taking into consideration a number of factors including "the original cost of construction, the amount

*A.B., Harvard, 1920; LL.B., San Francisco Law School, 1923. Member of the California Bar.

1 Federal Power Commission v. Hope Natural Gas Co. (1944) 320 U. S. 591.

2 (1898) 169 U.S. 466.

3 It was so characterized by Justices Black, Douglas and Murphy in their concurring opinion in the Natural Gas Pipeline case. See Hale, Does the Ghost of Smyth v. Ames Still Walk? (1942) 55 HARv. L. REv. 1116.

4 (1942) 315 U. S. 575.

5 Mr. Justice Jackson said in his dissent: "The Court sustains this order as reasonable, but what makes it so or what could possibly make it otherwise, I cannot learn." Supra note 1, at $645,646$.

6 Smyth v. Ames, supra note 2, at 546. 
expended in permanent improvements, the amount and market value of its (i.e., the company's) bonds and stocks, the present as compared with the original cost of construction, the probable earning capacity of the property under particular rates prescribed by statute, the sum required to meet operating expenses." The commission was supposed to give to each of these factors "such weight as may be just and right in each case."7

In the late twenties the Supreme Court finally acknowledged that a rate base could be fixed on original cost or reproduction cost, but not on both, and threw its weight in favor of reproduction cost. ${ }^{8}$ This selection was a great disappointment to most regulatory authorities who naturally favored the original cost or prudent investment theory so ably presented by $\mathrm{Mr}$. Justice Brandeis in his concurring opimion in the Southwestern Bell Telephone case, ${ }^{9}$ as it is obviously simpler to make one finding of original cost than to have to make findings of reproduction cost every time rates are considered. As a result, the reproduction cost or "fair value" theory has been under constant attack and criticism and has suffered gradual encroachment until the Hope case which is supposed to have finally eliminated it from the law of rate inaking by the following language:

"The fixing of prices, like other applications of the police power, may reduce the value of the property which is being regulated. But the fact that the value is reduced does not mean that the regulation is invalid. It does, however, indicate that 'fair value' is the end product of the process of rate-making not the starting point as the Circuit Court of Appeals held. The heart of the matter is that rates cannot be made to depend upon 'fair value' when the value of the going enterprise depends on earnings under whatever rates may be anticipated." 10

The Court does not say that rates should not or that they need not be fixed at a level to provide a return on the value of the property-the Court's conclusion is that the rates cannot be fixed at this level because there is no way of fixing value without first fixing the rates. Is this true? Value is the price at which willing buyers and

7 Ibid. at 547 .

8 McCardle v. Indianapolis Water Co. (1926) 272 U. S. 400 and St. Louis \& O'Fallon Ry. Co.v. U.S. (1929) 279 U.S. 461.

9 Southwestern Bell Telephone Co. v. Public Service Commission (1923) 262 U.S. 276.

10 Supra note 1 , at 601 . 
sellers will make a deal. ${ }^{11}$ Since utility properties are not customarily dealt in on a market, we have no way of determining their value directly so we must resort to other measuring sticks. While one might agree that capitalized earning power is the next best gauge of value, is there not another reasonably good one and, if so, must we discard the idea of basing rates on value merely because the second best gauge is not available? If we had no idea of the earning power of a property, would we have any way of estimating its value? If a house or a store burns down does the owner collect his fire insurance based on earning power? Not at all-his loss is ascertained by estimating replacement cost. Similarly if an automobile is damaged or a valuable article stolen.

Without arguing the point at length, which is not the purpose of this article, it is evident that cost of reproduction is at least a reasonable test of value. Furthermore, it should not be too difficult to apply in the light of the mass of data which has been accumulated on the subject in the past twenty-five years. With a few principles settled in advance such as propriety of including going concern value, whether the appraisers are to assume conditions prevailing at the time of construction or at the present time, and whether the appraisers are to assume wholesale or retail construction, the engineering staffs of the utility and the commission should have no trouble in agreeing on the reproduction cost figure.

Moreover, even if reproduction cost were not a fair measure of value, why is it not in and of itself a fair rate base? If rates are to be fixed at less than the public would pay without regulation, should they not be at least high enough to cover the cost of carrying the investment that would have to be made to reproduce the service?

If reproduction cost is to be disregarded, how else would we handle the problem of inflation? With our debt mounting at some unknown rate approximating eight billion dollars a nonth, it is not inconceivable that we will have a readjustment of our currency such as took place in France after the last war with the result that it will take $\$ 5$ to buy what $\$ 1$ can buy now. If it would cost $\$ 100,000$ to duplicate a water system serving a small town, is this fact to be ignored and the owner limited to something like a 6 per cent return on an original cost of $\$ 20,000$ ?

11 Webster's definition is: "The value of a thing is what it would bring on the market. ... In political economy, worth as estimated by the power of purchasing or being exchanged for other commodities." 
However, serious inflation is not with us now, but there is another danger against which we must guard if we do not relish buying the necessities of life from the same management that runs the OPA, WLB, etc. If the government sets out to condemn utilities, we would not expect it to pay more than their value. Now if value is determined by rates and rates need have no relation to a predetermined value or to reproduction cost, there is no escape from the conclusion that any utility might be condemned by some government agency at a price which bears no relation to real value or to reproduction cost. For what is to prevent the government from fixing rates on one of the novel court-approved theories hereinafter mentioned at such a level as to produce a fair return on only half the cost of reproducing the property and then finding the value of the property as determined by the rates so fixed to be half its reproduction cost and condemning the property for the value so found? Such a result is such obvious thievery and involves such an obvious disregard of the fifth amendment to the Constitution ${ }^{12}$ that it is reasonable to suppose we have not heard the last of reproduction cost despite the Court's attempt to abolish it forever as a factor in rate-making. Perhaps Justices Black, Douglas and Murphy were worried about this evident result of their rate-making innovations when in their concurring opinion in the Natural Gas Pipeline case they attempted to make a distinction between taking title to property away from the owner at less than "full money equivalent" and leaving title to the owner while taking the use at less than full money equivalent. ${ }^{13}$ This type of distinction may satisfy lawyers and academicians but manifestly would hold no appeal to a businessman who could not tell the difference in his pocketbook.

With these passing comments on the Court's one supposed accomplishment we turn to an examination of the extraordinary confusion created by the balance of the opmion.

Hope Natural Gas Company is a wholly owned subsidiary of Standard Oil Company (N.J.) engaged in producing, transporting and selling natural gas. Its capitalization consists solely of common stock- $\$ 17,000,000$ issued for cash and other assets and an additional $\$ 11,000,000$ issued as stock dividends. By foregoing cash divition."

12 ". . . nor shall private property be taken for public use without just compensa13 Supra note 4 , at 603 . 
dends and reinvesting earnings, Hope had put into its properties a total of $\$ 50,700,000$ but the Commission disallowed $\$ 17,000,000$ of this investment and found a prudent investment rate base of $\$ 33$,700,000 . The disallowed $\$ 17,000,000$ consisted of capital investment in wells drilled prior to 1923 and was ruled out on the ground that the company had followed the practice prior to that date of charging these capital costs to operating expense. The Commission found that $6 \mathrm{~T} / 2$ per cent was a reasonable rate of return and fixed rates which would produce this return $(\$ 2,200,000)$ on the $\$ 33,700,000$ rate base. The Circuit Court held that "present fair value", which greatly exceeded cost, was the proper rate base and set aside the Commission's order.

After reviewing the facts, the Supreme Court opens with the following:

"We held in Federal Power Commission v. Natural Gas Pipeline $C o$. that the Commission was not bound to the use of any single formula or combination of formulae in determining rates."14

Does this mean that the Commission has a choice of several formulae or that it need not follow any formula at all? One's first natural reaction to this question is that the Court no doubt assumed that the Commission would and probably should have some articulated process of arriving at its conclusion. It is hard to believe that the Court would countenance regulation by a species of crystal-gazing or soul-searching which announces the result without method. Yet that is just what a majority of the California Railroad Commission thinks it is now privileged to do. Citing the Hope case as authority, the Commission said: ${ }^{15}$ "The Commission in a proceeding of this nature is not required to use a specific formula in determining just, fair and reasonable rates. ... We desire however to state clearly the basis upon which our decision rests and what factors were given consideration in reaching our conclusion." The Commission evidently gave its reasons as a result of its conception of fair practice, not because it considered itself obligated to do so. Moreover, in support of the Commission's conclusion, consider the following remarks from the Hope case:

"And when the Commission's order is challenged in the courts, the question is whether that order 'viewed in its entirety' meets the

14 Supra note 1 , at 602 .

15 In re California Street Cable Railroad Company (1944) Decision No. 37167. 
requirements of the Act. Under the statutory standard of 'just and reasonable' it is the result reached not the method employed which is controlling. ... It is not theory but the impact of the rate order which counts. If the total effect of the rate order cannot be said to be unjust and unreasonable, judicial mquiry under the Act is at an end. The fact that the method employed to reach that result may contain infirmities is not then important."16

If it is immaterial what method the Commission followed as long as the end result is justifiable, and if the result is the sole test of validity, what difference does it make if the Commission does not say or even really know how it reached the result? For all that appears to the contrary a commission after hearing the evidence could merely announce that it has a feeling in its bones that five cents per kilowatt hour is a proper charge and fix rates accordingly.

Such a system of rate fixing may not result in confiscation, but is it due process of law? When a rate is attacked in the courts, what will the procedure be? The Court, in the Hope case, says that a rate fixed by a commission is "the product of expert judgment which carries a presumption of validity. And he who would upset the rate order under the Act carries the heavy burden of making a convincing showing that it is invalid because it is unjust and unreasonable im its consequences." 17 Must a coinpany think up all the possible methods of setting rates and show that those fixed by the Commission are improper under any one of these methods?

When in addition to this chaotic novelty the company is faced with the fact that the Court has not supplied any fixed yardstick by which to measure the Commission's decision, the task of securing relief from an unjust rate order becomes almost insuperable.

If the reader has any tendency to doubt the fact that the Court will use as many yardsticks as it has a mind to in order to test rate orders, let him consider the following:

"Nor is it important to this case to determine the various permissible ways in which any rate base on which the return is computed might be arrived at."

Since the Court refers to "various permissible ways" of arriving at a rate base and since outside of origimal cost the only other recognized rate base is reproduction cost (or perhaps a combination of

16 Stzpro note 1 , at 602 .

17 Ibid. 
the two) it appears to be probable that the Court would uphold rates if fixed on reproduction cost. In other words, if a plant cost $\$ 10$,000,000 and could be reproduced for $\$ 5,000,000$, it is a reasonable conclusion from the decision, that rates fixed to yield a return on the $\$ 5,000,000$ would not be set aside. It thus appears that we are back to the old plan supposed to have been originally sponsored by William Jennings Bryan that rates be fixed on original cost or reproduction cost, whichever is lower. There is nothing im the decision to indicate that the Commission could not apply an original cost rate base to one company and a reproduction cost rate base to another, or even that it could not apply an original cost rate base to a company in time of high prices and reproduction cost rate base to the same comyany in a time of low prices. This seems so outrageous on its face that the natural tendency is to say that the Court couldn't mean any such result. However, we should have learned by now that the fact a statement appears outrageous is no reason to comfort ourselves with the thought that it was not intended.

Justices Douglas, Black and Murphy leave us with little doubt as to what they at least intended since they said in their concurring opinion in the Natural Gas Pipeline case: "Various routes to that end (the fixing of just and reasonable rates) may be worked out by the expert administrators charged with the duty of regulation. It is not the function of the courts to prescribe what formula should be used. The fact that one may be fair to investors does not mean that another would be unfair."18

Moreover the uncertainty is in itself an evil situation. If the utility investor is really putting his money into a "heads I win-tails you lose" proposition, it is at least fair to tell him so in order that he may try some other source of investment until the law is changed.

We now come to a remarkable statement, to-wit: "Its (i.e., the Commission's) rate-making function moreover involves the making of 'pragmatic adjustments.'

What are these practical adjustments? Is this some further loophole to justify any result which the whims of a commission may produce? The Court does not trouble to explain the meaning of this expression, and a search of the Natural Gas Pipeline case from which the expression arose is unrevealing.

\footnotetext{
18 Supra note 4, at 607 .

18 Supra note 1 , at 602 .
} 
Here is another one: "The conditions under which more or less might be allowed are not important here." 20

In the absence of any explanation, this remark only adds to the obscurity.

Next comes:

"The rate making process under the Act, i.e., the fixing of 'just and reasonable rates', involves a balancing of the investor and the consumer interests. Thus we stated in the Natural Gas Pipeline Co. case that 'regulation does not insure that the business shall produce net revenues'." 21

Since the holding that regulation does not insure net revenues is so well established and has never before needed the support of any principle of balancing interests, we are perhaps justified in thinking that the Court has attempted to fortify a doubtful principle by attaching to it an undisputed conclusion derived from another source.

Just what is this balancing of the investor and consuuner interests? Is this some new theory of rate making and, if so, what are the methods by which this balancing can be accomplished? The consumer is "interested" in having rates as low as possible and the investor is "interested" in having rates which will produce the highest net income, but these are desires, not legal interests which the commissions and courts ordinarily recognize and protect. Most of us have thought that consuners are entitled to rates no higher than necessary to provide a reasonable return to the investor and that the investor is entitled to the saine thing. So what is the function of doing any balancing?

One might conclude that this remark of the Court was meaningless rhetoric or "caunpaign oratory" except for the concurring opinion in the Natural Gas Pipeline case where it was said, "The consumer interests cannot be disregarded in determining what is a 'just and reasonable rate.' . . . A return to the company for the cost of service might not be 'just and reasonable' to the public. ... The investor and consuner interests may so collide as to warrant the rate making body in concluding that a return on historical cost or prudent investment though fair to investors would be grossly unfair to the consumers."

\footnotetext{
20 Ibid. at 603 .

21 Ibid. at 602 .

22 Supra note 4, at 607,608 .
} 
We have here fair warning that a rate which provides only a just and reasonable return to the investor may be lowered to the point that the investor is treated unjustly and unreasonably if some unnamed "consumer interest" demands it. It thus appears that the process of balancing resolves itself into deciding how unjust we may be to the investor, and we are furnished with no standard of injustice other than the subjective reactions of the "expert administrators charged with the duty of regulation."

As we have seen, if we are to test a commission's orders by the "end result", it is vital that there be some test of the end result. A bit further along in the opinion the reader may start to hope that some rational ineans of testing the end result is to be declared. The Court says: "From the investor or company point of view it is important that there be enough revenue not only for operatimg expenses but also for the capital costs of the business. These include service on the debt and dividends on the stock." ${ }^{23}$

Preliminarily we pause to note that the last quoted sentence is so vague as to be ineaningless. "Service" of a debt usually means the periodic principal payments as well as interest, but the Court does not indicate whether it uses the term in this sense and, if so, what percentage of principal is to be paid annually from revenues, or whether these principal payments are to be treated as an operating expense or deducted from the investor's return. And obviously the Court's concern about dividends will not, in the absence of some expression as to the proper anount, do much to relieve the anxiety of an investor who would like more than a $\$ 1$ dividend on a $\$ 100$ investnient.

However, let us proceed with the next sentence, which looks at first like the real thing. "By that standard (sic) the return to the equity owner should be commensurate with returns on investments in other enterprises having corresponding risks." ${ }^{24}$ In other words, the "return" (the income received from the investment) should be "comniensurate with" (measured by or approximately the same as) the income which can be derived fron equally sound investments. More briefly, the owner is entitled to a reasonable return on his investment. Here we have the prudent investment theory, which, al-

23 Supra note 1, at 603 .

24 Ibid. 
though it may work an injustice in some cases, is at least simple, understandable and workable.

However, the investor's peace of mind will be short-lived because it is not many paragraphs beyond that the Court decides the case on an entirely different theory, which is discussed below. And just to prove it doesn't intend to be bound by the prudent investment theory, the Court adds: "In view of this disposition of the controversy (i.e., the rate making sentiments on which the court decided the case) we need not stop to inquire whether the failure of the Commission to add the $\$ 17,000,000$ of well drilling and other costs to the ratebase was consistent with the prudent investment theory as developed and applied in particular cases." In other words, the Court is saying that even if, under the prudent investment theory, the proper ratebase for the company was $\$ 51,000,000$ it would, under its own new theory, uphold rates which produced a return on only $\$ 34,000,000$. When the Court is prepared to lop off one-third of a rate-base without stopping to inquire about it there could hardly be clearer notice that the Court does not intend to be bound by the prudent investment theory.

Perhaps this $\$ 17,000,000$ deduction is what is meant by a "pragmatic adjustment," and that any attempt to explain it involves attributing to the decision a rationality which the Court does not intend. However, since the Court traditionally has a logical reason for its conclusions, it is inevitable that attempts will be made to discern one in this instance so that it may be applied to similar situations. As the company charged these capital outlays to operating expense, the first thought that comes to mind is that the Court was of the opinion that the company should be bound by its accounting methods even though they were corrected fifteen years before the company became subject to regulation under the statute in question. However, to visit such a penalty on the company for an accounting mistake or a conservative instinct of its auditors is too capricious an action to be taken as a serious possibility. As Mr. Justice Jackson said in his dissent,

"This attributes a significance to formal classification in account keeping that seems inconsistent with rational rate regulation. Of course, the Commission would not and should not allow a rate base to be inflated by bookkeeping which had improperly capitalized ex- 
penses. I have doubts about resting public regulation upon any rule that is to be used or not depending on which side it favors." 25

A more reasonable interpretation is that the Court's action was predicated on a desire to offset the company's large earnings in the unregulated past which permitted an ample return even after deducting these charges.

Thus the nebulous quality of the decision has managed to throw into confusion another important issue which had previously been settled, i.e., that neither past losses nor past profits should be taken into consideration in fixing rates for the future. ${ }^{23}$

Professor Hale views this result with composure if not approbation. ${ }^{2}$ In support of the notion that high income of the past justifies ignoring the additional investment made with this income, he grants that stockholders would not permit earnings to be reinvested without assurance of a fair return on the additional investment if they could secure the earnimgs in dividends without encountering any compensating loss in doing so. He then adds,

"But would they encounter no compensating loss? They surely would, as to so much of the earnings as must be put back if depreciation is to be adequately provided for. Failure to invest that much in the property will result ultimately in the disappearance of their property, with nothing to show for it." 28

Since for years no one has questioned the fact that depreciation must be fully provided for before there are any earnings (i.e., net income), the reaction of investors will not be favorable to the premise that an investment will dwindle to nothing unless net income is used to replace it. Fortunately, this startling suggestion was Professor Hale's own-it was not sponsored by the Court.

He concludes his comments on the subject with the apparent hope that the Court will approve adjustments of a rate base by deduction

25 Ibid. at $643,644$.

26 See Los Angeles Gas \& Electric Co. v. Railroad Commission (1933) 289 U.S. 287, where the Court said: "Deficits in the past do not afford a legal basis for invalidating rates otherwise compensatory any more than past profits can be used to sustain confiscatory rates for the future," and similar statements in Board of Commissioners v. New York Telephone Co. (1926) 271 U.S. 23 and Newton v. Consolidated Gas Co. of New York (1922) 258 U.S. 165.

$2 \pi$ Hale, Utility Regulation in the Light of the Hope Natural Gas Case (1944) 44 Cor. L. Rev. 488, 504-520.

28 Ibid. at 508 . 
of surplus earnings and addition of deficiencies. This is an idea which could only have come from the classroon. The public is far more interested in good service than in minor adjustnients in rates and in order to supply good service, someone has to put up the money for extensions and nothing will inhibit investment niore surely than uncertainty as to the matter of return. It is hard enough for an investor to conprehend the present position of a utility without having to review its entire history to determine whether its rates have afforded more or less than a reasonable return and the consequent effect on its rate base. An expert analyst might conceivably have undertaken such a task in the past but it has been rendered impossible by the Hope case.

The disallowance of this $\$ 17,000,000$ of well drilling costs raises another question for which no answer can be found in the opinion.

Let us suppose that the Commission had included the $\$ 17,000,000$ in a prudent investnient rate-base and that the Court had decided that this inclusion was proper. The net income on the resulting $\$ 51$,000,000 rate-base at a $61 / 2$ per cent return would have been $\$ 3,300$,000 instead of $\$ 2,200,000$. If these rates had been attacked by the company as too low and by the public as too high, what would the Court have decided? We can only speculate on the answer but in the light of the free hand which the Court apparently wants to give the Commission, it would be a fair guess that the Court would not have disturbed the Commission's order. And yet, under its decision, it held that rates which produced only $\$ 2,200,000$ were just and reasonable. So how could rates which produce 50 per cent niore be likewise just and reasonable unless the Court has expanded these words to such an extent that they are practically meaningless?

We now conie to the only three sentences in the opimion which express any basis for the decision. The first two are:

"The Commission concluded, 'The company's efficient management, established markets, financial record, affliations, and its prospective business place it in a strong position to attract capital upon favorable terms when it is required.' In view of these various considerations we cannot say that an annual return of $\$ 2,191,314$ is not 'just and reasonable' within the meaning of the Act." 29

The only thing that resenibles a rate making theory in this passage is the suggestion that rates which permit a conpany to attract

29 Supra note 1, at 605 . Italics supplied. 
capital are sufficient. This thought is repeated in the next sentence which will be discussed below, but it is fair to inquire in passing whether a company with inefficient management is entitled to higher rates than one with efficient management. How would such a doctrine affect service to the public?

In the next sentence we are presented with the following four tests unadorned by any further explanation:

\footnotetext{
"Rates which enable the company to operate successfully, to maintain its financial integrity, to attract capital, and to compensate its investors for the risks assumed certainly cannot be condemned as invalid, even though they might produce only a meager return on the so-called 'fair value' rate base." 30
}

Let us apply these tests to a company with 100 million dollars of stock divided into one million shares sold for $\$ 100$ per share, no bonds (as was the case with Hope Natural Gas Company) and earnings of six million for the past year which have just been reduced to two million by Commission order. Is the order valid? A company that can earn two million a year is certainly not operating unsuccessfully and a company with these earnings and 100 million dollars of property should have no troubles with its financial integrity. Consequently, the order passes the first two tests with flying colors.

Could this company attract capital? It could not sell common stock at $\$ 100$ a share, but it could, no doubt, sell bonds or preferred stock as suggested by Professor Hale as its "only escape from this dilemma." ${ }^{31}$ Moreover, in addition to this "only escape" there is obviously some price at which it could sell common stock. If the common stock were originally of $\$ 100$ par value and the state of incorporation would not permit the sale of additional stock at the best price obtainable below par, the company could readily change its stock to no par value or reduce the par to the proposed selling price. So the order appears to pass this third test.

Professor Hale assumes, without explaining why, that new common stock cannot be sold for less than the par value of the original issue. He pictures a case where a utility "has not pursued a conservative policy in respect to its capitalization" and "has issued stock whose par value exceeds the actual cost of the property" and is thus

$30 \mathrm{Ibid.}$ at 605.

31 Op. cit. supra note 27 , at 502 . 
unable to issue further stock at par. He points out that in such a case "a fair return on actual cost (or prudent investment) inay not suffice to enable a company to attract new capital when needed" and then, concludes "it might be expedient in such a case, from the point of view of consumers, to allow more than a fair return on actual cost, for consumers might suffer from the company's inability to expand."32

Utility lawyers whose duty it is to think up reasons why rates should be increased or maintained, are here presented with a brand new tool of their trade. All they need is the courage to try it out on some commission, but it is suggested that the experiment be inade in some state other than Cahifornia as it is not believed that the California Commission would treat seriously the notion that a company should be granted higher rates because it has watered its stock. The only fair remedy is not higher rates but forcing the company to recapitalize, which it would probably do voluntarily if it could not raise capital otherwise, and which it would probably be forced to do by the Commission through orders which would restrict dividends or through threatened competition.

Perhaps it does Professor Hale an injustice to assume that he gets himself in this dilemma by starting with the incorrect premise that additional stock cannot be sold below the par value of the original issue. Perhaps, although he does not say so, his real point is that the words "to attract capital" in the Supreme Court decision mean "to attract capital at the par value of the outstanding securities." Such an interpretation would no doubt be welcomed enthusiastically by promoters but would be rejected with equal alacrity by the public. There is obviously no reason why a utility which "has issued stock whose par value exceeds the actual cost of the property" should thereafter be awarded rates high enough to enable it to issue additional stock at par value for cash.

Another possibility is that Professor Hale interprets the words "to attract capital" to mean "to attract capital on the same basis that the original capital was secured." In other words, a utility which had originally issued stock at $\$ 100$ per share would be entitled to rates which would enable it to issue additional stock at not less than this price. If by any chance this is what the Supreme Court means, it presents a perfectly possible theory of rate making but one which is utterly impracticable. For example, if we assume that the average

32 Ibid. 
price at which American Telephone stock was issued was $\$ 100$ per share, would not the public be in a position of guaranteeing this price by offering a rate increase whenever the stock fell below?

It may be objected that a commission would not be concerned with temporary fluctuations in the market, but the answer to this objection is that no one has yet been able to devise a method of telling how temporary a fluctuation of the stock market may be, and there is no doubt that while the stock is below $\$ 100$ a share it would be impossible to sell more stock at this price. Even though the price on a stock exchange may control the ability of a company to finance, it is unlikely that the public would willingly accept the idea that its telephone and electric rates would vary with the stock market, and for the many sunaller companies not listed on the stock exchange there would be no feasible test at all of whether they could finance at the price of their original issues.

The conclusion is suggested that in using the words "to attract capital" the Supreme Court did not know just what it did mean and that Professor Hale takes undue liberties with the decision in attempting to put some substance on to this shadowy thought.

To summarize, it seems clear that these first three tests are meaningless, at least when applied to a company such as Hope Natural Gas Company. Any rate which would permit it to operate at a profit would permit it to operate "successfully", maintain its financial integrity and attract capital on some terms.

The fourth and last test is "to compensate its investors for the risks assumed." The investors referred to must be the old investors as the new ones will be taken care of when their capital is attracted. Now the only way in which investors can be compensated is through a return on their money. The word "compensate" implies a fair measure of return and, consequently, if these words mean anything at all, they must mean that the investor is to receive a fair return on his original investment, and, here we are right back to the pru- . dent investment theory of rate making.

However, if there is one thing clear about the decision, it is that the Court does not accept the prudent imvestment theory as binding; so we are again left up in the air as to Court's intentions.

The Court may be incliming toward the idea that the investor's compensation should be calculated not on the amount the company originally invested (the prudent investment theory) but on the 
amount the investor originally paid into the company. It is hardly credible that the author of the opinion, a former college professor and member of the Securities and Exchange Commission, would entertain such a primitive idea of economic justice, but the decision is otherwise so incomprehensible that every possibility must be considered.

Suppose the stockholders of two compamies each contributed $\$ 100,000,000$ and the companies each prudently invested this amount. Suppose further that the rates were originally fixed to provide an income of 6 per cent on the amount invested, that Company A has paid out all its earnings in dividends but that Company $B$ has withheld dividends from its stockholders and from this source prudently invested another $\$ 50,000,000$ in property with the result that it is earning $\$ 9,000,000$ while Company $\mathrm{A}$ is still only earnimg $\$ 6$,000,000 . If we are to regard only the return to the investor on the amount originally invested, the Commission would be free to cut Company B's rates so as to leave a net incoine of only $\$ 6,000,000$. Such a result would obviously be harmful both to the investor and the public as it would conpletely put a stop to the sound practice of reinvesting a portion of earnings in additional plants and compel companies to pay out all their earnings in dividends as fast as possible.

If any reader thinks there must be soine explanation in the decision which has been overlooked, he may save himself the trouble of a search by considering the observations of two of the decision's apologists.

John Bauer says:

“. . No particular rate base provisions are imposed, provided that the rates as fixed are all-around 'just and reasonable.'

"... the court is now bound to disregard the methods and procedure by which the rates have been fixed and to consider only the apparent reasonableness of the resulting rates. For such consideration there is no technical yardstick, but the showing of unreasonableness must be convincing.

". . . The judicial criteria of invalidity are, then, left quite indefinite, presumably to preclude the imposition of formulae and the shackling of regulation. Without specific measurements, the showing of the petition for review inust be conclusive that the rates are inadequate, not merely injuring the investors unjustly, but preventing 
proper service to the public. The task of future regulation is lodged practically in its entirety in the commissions, and courts retain only the rigorously limited function of preventing really unjust and destructive administrative action." 33

and says Professor Hale:

". . While other exercises of the police power do not have to avoid uncompensated destructions of value, the Court still exercises the power to declare them unconstitutional deprivations of property if they seem to it 'arbitrary' beyond the limits of tolerance which it feels disposed to observe. This test is not readily reducible to a formula. Perhaps the Court meant in the Hope case to substitute no definite formula for the rule of Smyth v. Ames, but instead to decide the constitutionality of each future rate case by the necessarily vague test of 'arbitrariness'." 84

To summarize the major problems created or rejuvenated by this decision, we have the following:

1. Can utility properties be condemned at a "value" determined by rates fixed without relation to original or replacement cost?

2. Can rates be fixed by announcement of the result without explaining the basis?

3. If so, what is the procedure and the burden of proof to be assumed by the utility if it desires to challenge the rates in the courts?

4. What are the "pragmatic adjustments" which a utilities commission can make?

5. What are the "various permissible ways" of arriving at a rate base?

6. Can a commission employ different methods of arriving at a rate base from time to time for the same utility according to which produces the lowest rates?

7. What are the unexplamed "conditions under which more or less imight be allowed"?

8. Is there only one just and reasonable rate at any given time or is there a wide range of permissible rates?

9. What is the process of "balancing the investor and consumer interests" which will permit of reducing rates to the point where they

33 Bauer, The Establishment and Administration of a "Prudent Investment" Rate Base (1944) 53 YALE L. J. 495, 504, 505. Italics supplied.

34 Op. cit. supra note 27 , at 497 . 
are unjust to the investor? What are these consumer interests, how are they balanced, and is there any limit to the reductions which can be accomplished in this fashion?

10. Can past profits, earned before or after regulation, justify rates which currently produce less than a fair return?

11. Is inefficient management a valid argument for higher rates?

12. Was there actually any test at all applied by the Court in determining whether Hope's rates were proper and, if so, what was it?

Serious as the consequences of this decision may be to investors, the great damage is to the public. Vigorous utilities, striving to supply more and better service, are the primary consideration. And if we are to have this type of utility, we must assure it of the capital to work with, which means we must assure investors of just treatment. A practical, understandable, fair method of rate-1naking established by legislative action is the only remedy. 